\title{
Painless Complex Regional Pain Syndrome in an Old Man
}

\author{
Yaşlı Bir Hastada Ağrısı Kompleks Bölgesel Ağrı Sendromu
}

Ayhan Kul, Fatih Bağcıer, Mahir Uğur

Atatürk University Faculty of Medicine, Department of Physical Medicine and Rehabilitation, Erzurum, Turkey

\section{To the Editor;}

A 62-year-old man presented to our outpatient clinic with the complaints of swelling and restriction of finger and wrist movements of his left hand. He provided history of distal radius fracture on his left hand two months prior to presentation to the our clinic. Following the trauma, the patient had been treated by immobilization in a cast for six weeks. He had no pain. On examination of the skin of the affected hand; wrist was swollen (non-pitting), hot, and was not tender to touch (Figure 1a). There was no hyperhidrosis, tremor, allodynia and hyperalgesia. Range of motion was restricted at the wrist and fingers. X-ray

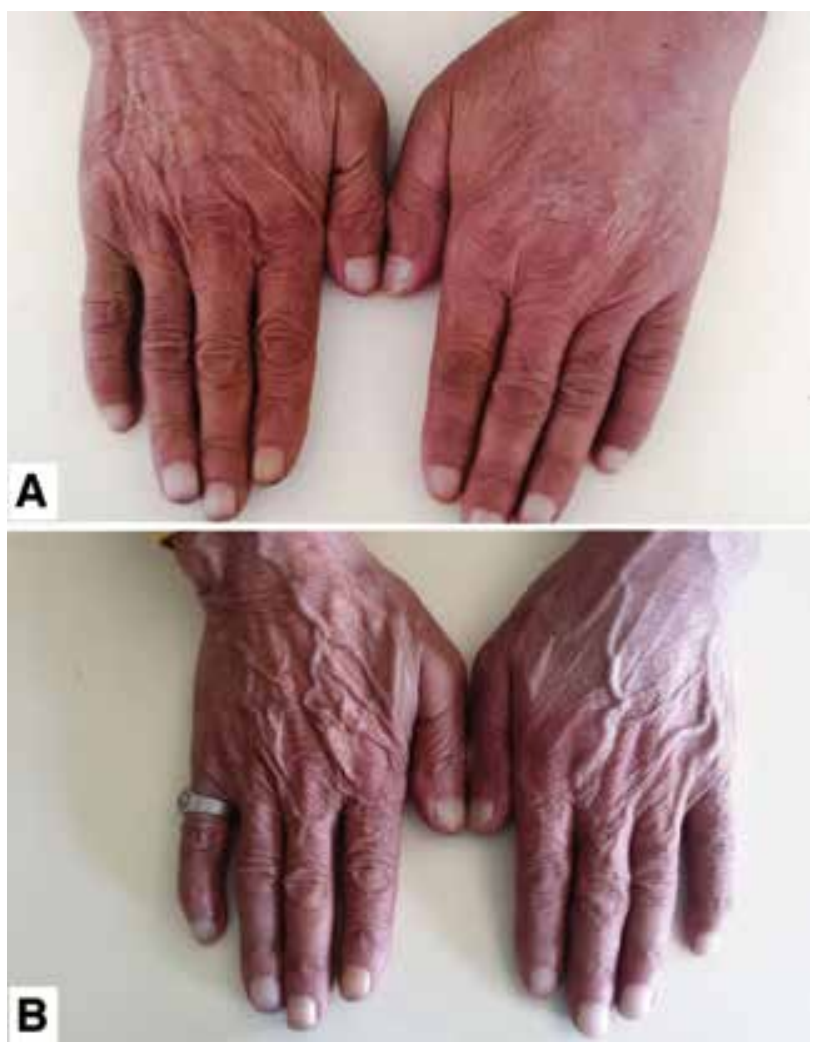

Figure 1. a) Before treatment, b) After treatment of the hand showed demineralization of the bones of the hand. A bone scan was performed and there was milder non-specific diffuse increased uptake in the remaining left wrist region (Figure $2 a, 2 b)$. Based on these findings, the patient was diagnosed as complex regional pain syndrome (CRPS) type 1 according to Zyluk scoring system (1). Physical therapy modalities and medical treatment was planned. In the physiotherapy program; range of motion exercises, contrast baths (four cycles over a 20 minute period), whirlpool bath (15 minutes), retrograde massage, pulse ultrasound (1 watt $/ \mathrm{cm}^{2}$ ) was performed. The patient was administered intravenous methylprednisolone $30 \mathrm{mg} /$ day pozology for a week. After the 20 sessions of physical therapy and medical treatment, the patient's signs and symptoms markedly improved as compared to the initial examination (Figure 1b). Active and passive wrist flexion was full and he did not report any pain at the control visits.

According to the International Association for the Study of Pain criteria of 1994, pain, evidence of change in blood flow or abnormal sudomotor activity and the absence of conditions that would otherwise account for symptoms are essential diagnostic entities of CRPS type 1 (2,3). Eisenberg and Melamed (4) reported a series of five patients with various foot pathologies who had presented with all of the criteria of CRPS except pain.

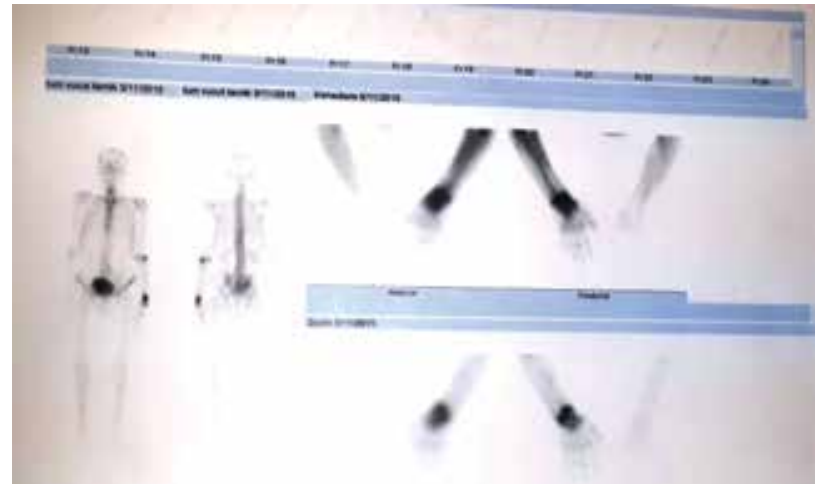

Figure 2. There was milder non-specific diffuse increased uptake in the remaining left wrist region 
Veldman et al. (5) reported a series of 829 patients with CRPS and among them, $7 \%$ of the patients did not have pain as a symptom. This case report presented a patient who developed full-blown clinical pictures of CRPS subsequent to trauma, but had neither spontaneous pain nor any hyperalgesia/allodynia etc. The literature suggested that the autonomic, motor, and trophic signs and symptoms of CRPS are not necessarily coupled with either ongoing or evoked pain and point to the existence of a relatively unrecognized syndrome, for which we suggest the name CRPS.

Keywords: Painless, complex regional pain syndrome, radius fracture

Anahtar kelimeler: Ağrısız, kompleks bölgesel ağrı sendromu, radius fraktürü

\section{Ethics}

Peer-review: Internal peer-reviewed.

\section{Authorship Contributions}

Concept: Fatih Bağcıer, Design: Fatih Bağcıer, Data Collection or Processing: Fatih Bağcıer, Analysis or Interpretation: Fatih
Bağcıer, Literature Search: Ayhan Kul, Mahir Uğur, Writing: Ayhan Kul.

Conflict of Interest: No conflict of interest was declared by the authors.

Financial Disclosure: The authors declared that this study has received no financial support.

\section{References}

1. Zyluk A. A new clinical severity scoring system for reflex sympathetic dystrophy of the upper limb. J Hand Surg $\mathrm{Br}$ 2003;28:238-41.

2. Reinders MF, Geertzen JHB, Dijkstra PU. Complex regional pain syndrome type 1: Use of the International Association for the Study of Pain diagnostic criteria defined in 1994. Clin J Pain 2002;18:207-15.

3. Dilek B, El Ö, Şahin E, Gülbahar S, Bircan Ç, Akalın E. Ağrısız Seyreden Kompleks Bölgesel Ağrı Sendromu: Olgu Sunumu. Türk Fiz Tıp Rehab Derg 2008;54:127-9.

4. Eisenberg E, Melamed E. Can complex regional pain syndrome be painless? Pain 2003:106:263-7.

5. Veldman PHJM, Reynen HM, Arntz IE, Goris RJ. Signs and symptoms of reflex sympathetic dystrophy: Prospective study of 829 patients. Lancet 1993;342:1012-6. 